Hydrol. Earth Syst. Sci. Discuss.,

https://doi.org/10.5194/hess-2019-643-AC1, 2020

(c) Author(s) 2020. This work is distributed under

the Creative Commons Attribution 4.0 License.
Hydrology and

\title{
Interactive comment on "Intensification
}

characteristics of hydroclimatic extremes in the Asia monsoon region under 1.5 and $2.0^{\circ} \mathrm{C}$ of global warming" by Jeong-Bae Kim and Deg-Hyo

\section{Bae}

Jeong-Bae Kim and Deg-Hyo Bae

dhbae@sejong.ac.kr

Received and published: 3 May 2020

Please see of supplementary file.

Please also note the supplement to this comment:

https://www.hydrol-earth-syst-sci-discuss.net/hess-2019-643/hess-2019-643-AC1-

supplement.zip 
643, 2020.

HESSD

Interactive

comment

Printer-friendly version

Discussion paper

(c) (i) 